\title{
Reason, Justice, Cannibalism
}

Utopian themes in the fiction of James Meek

\section{David Leishman}

\section{(2) OpenEdition}

Journals

Electronic version

URL: http://journals.openedition.org/etudesecossaises/79

DOI: 10.4000/etudesecossaises.79

ISSN: 1969-6337

\section{Publisher}

UGA Éditions/Université Grenoble Alpes

\section{Printed version}

Date of publication: 30 January 2008

Number of pages: 127-142

ISBN: 978-2-84310-110-6

ISSN: 1240-1439

\section{Electronic reference}

David Leishman, «Reason, Justice, Cannibalism », Études écossaises [Online], 11 | 2008, Online since

30 January 2009, connection on 08 September 2020. URL : http://journals.openedition.org/

etudesecossaises/79; DOI : https://doi.org/10.4000/etudesecossaises.79

\section{This text was automatically generated on 8 September 2020}

(c) Études écossaises 


\title{
Reason, Justice, Cannibalism
}

\author{
Utopian themes in the fiction of James Meek
}

\author{
David Leishman
}

James Meek is known to some primarily as an award-winning journalist. After spending most of the 1990s in the former Soviet Union covering events for the Guardian, he reported on the war in Iraq, giving firsthand accounts of the effects of the war on ordinary Iraqis ${ }^{1}$. This reporting, combined with pieces on the conditions in Guantanamo $\mathrm{Bay}^{2}$, earned him international recognition and led to him receiving the British Press Association's Foreign Reporter of the Year award and an Amnesty International media prize, both in 2004. He now lives in London, from where he continues to contribute to the Guardian and the London Review of Books. He has written on subjects as varied as the use of torture by British and American forces, Anna Politkovskaya's reporting of the Chechen war, or the impact of GM crops.

It was not until 2005 that Meek also met with widespread critical acclaim and international success as a novelist, following the publication of his latest novel, The People's Act of Love ${ }^{3}$. He has, however, been producing fictional works since the late 1980s. His first novel, McFarlane Boils the Sea was published by Polygon in 1989 and this was followed by a collection of short stories, Last Orders in 1992. These early works tackle both social concerns and intimate, human dilemma: McFarlane Boils the Sea, for example, is set in a Scotland of empty dockyards and hostels for DHSS beneficiaries and focuses on a young woman uncertain about whether or not she should terminate her pregnancy. But Meek's writing also displays a dark humour by frequently allowing the social realism associated with Scotland's second literary renaissance to abruptly give way to scenes of absurdity and unreason.

In 1990 Meek was instrumental in setting up Clocktower Press with fellow writer Duncan McLean. Although the publications began as photocopied booklets which Duncan McLean admits could, at least initially, be seen as a form of "vanity publishing" for the two authors concerned, they contributed to the revitalisation of the Scottish literary scene by featuring new work from up-and-coming authors, including Gordon Legge, Irvine Welsh and Alan Warner, as well as that of more established authors such 
as Janice Galloway or James Kelman ${ }^{4}$. Drivetime, Meek's second novel, dealing with a futile, illusory quest across Europe, was published by Polygon in 1995. The novel marked something of a stylistic break with the author's previous work. Indeed, Drivetime's insistence on temporal and spatial discontinuity, coupled with the shortcircuiting of language's ability to order identity and experience (as foregrounded by the key character's double name, Alan Allen, and the multiple cases of namesake confusion or mistaken identity), mean that the novel shares many characteristics of David Lodge's definition of the postmodernist mode ${ }^{5}$.

By the mid 1990s, in the wake of the success of Trainspotting, the younger authors of the Scottish literary scene were being discussed, and marketed, as a recognisable literary school solidly grounded in a contemporary, urban Scotland. While this was particularly true if their fiction firmly grasped transgressive social realities such as teenage sex, violence or drug-taking, as in the case of Irvine Welsh and Alan Warner, James Meek also, to some degree, became identified with this so-called "Chemical Generation" of new writers. This was due in part to the offbeat surrealism that often worked its way into his writing, which, although often merely adding a degree of incongruity, whether humorous or disconcerting, to his otherwise recognisable fictional Scotlands, could sometimes be overtly hallucinatory in nature: the gyres of "Get Lost" which transform TV presenter Jackie Bird into a warped Central Belt of New Towns, seafood factories and oil refineries are a case in point (in Last Orders, p. 69-72). But Meek's prominence at this period is certainly also largely due to the inclusion of a short story of his in Rebel Inc.'s 1996 collection, Children of Albion Rovers, alongside works by Welsh, Legge and Warner. This collection, replete with football imagery, promised "a ragged kaleidoscope of urban under-dogs, bizarre beings and psychoactive users" according to its back cover. It played shamelessly on the notion of a youth culture which was both intoxicating and intoxicated, although it should be noted that Meek's offering, "The Brown Pint of Courage" featured not football hooligans and drug addicts, but traffic wardens, albeit unconventional ones engaged in a struggle with alcohol addiction. Rebel Inc. then published a second full collection of Meek's own stories in 2000, entitled The Museum of Doubt. These stories, in their construction of plausible, homely settings run through with mortal fear, dementia, and diabolical powers, seemed to confirm Meek's fondness for placing the uncanny at the heart of the familiar. Thus Meek's writing conforms closely to Todorov's definition of the fantastic ${ }^{6}$, and this, combined with the self-reflexive impulses of a novel like Drivetime, can be seen as contributing to a contemporary Scottish trend for "postmodern fantasy" identified in relation to Irvine Welsh and Alasdair Gray?

The People's Act of Love was enthusiastically received by the literary establishment, receiving two awards (Scottish Arts Council Book of the Year 2006; the Royal Society of Literature's Ondaatje Prize 2006) as well as being long-listed for the 2005 Booker Prize. Set in Siberia in 1919, the novel's historical and geographic focus makes it stand apart from much of Meek's earlier fiction, but so too does the temporal scope of its narration (the felicitous use of analepsis), the internal focus which gives a rich portrayal of the inner lives of multiple characters, and the finely-wrought phrases whose rhetorical flourishes, Meek explains, seek to convey the Russian idiom:

I think it's fair to say that the Russian culture of discourse is more about the fluency of the language. Of course you also want to get your point across, but you're aware that people will not just judge you for that, but rather more than in English than on the flow of the words coming out of your mouth. 
It may also be a reflection of the highly inflected nature of Russian. In that you can put the words in all sorts of different orders and still make sense but have different emphases. So, I think there's a slightly higher level of bombast and rhetoric even now in everyday Russian discourse ${ }^{8}$.

The novel's meticulous prose and propriety of tone contrast with the dark subject matter which, through its central preoccupation with cannibalism and castration, goes far beyond the mere quirkiness of earlier works. The two themes are intimately related: the undoing of the body's integrity points to the destruction of the individual at a purely physical level (as evidenced by the many descriptions of dismemberment, butchery, the honing of knives) but also at an ideological level, since both cannibalism and castration are practiced in the name of a cause. Drawing on historical sources which attest to the practice of prisoners escaping from the Gulag by taking a naïve, human "cow" along to provide food for the others; and to the presence of a Christian sect of castrates known as the Skoptzy, Meek associates bodily destruction with sacrifice in the name of a Utopian ideal. The novel's title refers to the justification of an act of cannibalism by an escaping anarchist revolutionary: the "people's act of love to itself" is to give up one of its own as food in order to ensure the sustenance of an agent of history toiling to bring about the destruction of the present order and the world's future happiness (p. 259-260). While recognising the novel's stark differences with earlier works, we shall endeavour to make apparent how the interwoven themes of the body and Utopian values also give a sense of continuity to Meek's fiction.

\section{The sacrifice of the flesh}

In literature, the Utopian community is characterised as the realisation of an ideal. It represents a form of governance which, in its perfection and stability, stands apart from time and history ${ }^{9}$. However, having first transcended the imperfections of the real, the purportedly timeless Utopian construction carries within itself the dim memory of change and upheaval, thus linking Utopia and revolution, stability and disturbance, in an uneasy dialectic ${ }^{10}$.

The theme of the bodily mutilation in The People's Act of Love foregrounds the relationship between worldly failings and Utopian perfection by focusing on the violence and destruction presupposed in the passage from one state to another. For the castrates of Yazyk, led by the character Balashov, this is achieved by ridding the body of the source of spiritual and physical impurity (the genitals, but also the breasts for female converts) which prevent true communion with God. The ablation of the sex organs is then followed by their annihilation as they are cast into fire. The resulting elimination of sexual identity and fecundity is indeed seen as a destruction of the human, but such is the desire of the skoptzy: "I am not a man. I have remade myself into the likeness and form of an angel." (p. 143) Castration and mammary mutilation represent a very real break with the natural cycle of human life - of procreation, maternity, suckling - and thus of development and change. The almost complete absence of children in the castrates' village allows the sect a sense of timeless perfection which they do not wish to interpret as merely a sterile void. The initial acts of violence preceding the Utopian state, and the consequent dehumanisation, are not eluded but rationalised as the necessary sacrifice of those who wish to attain, or rather return to, a more evolved spirituality. 
Similarly, the justification of cannibalism is presented by the anarchist revolutionary Samarin for whom the iniquitous social organisation of the present world cannot be transformed through anything other than the total obliteration of the existing order. Purportedly speaking of the psychopathic killer, the Mohican, his words relate to himself:

He's a man so dedicated to the happiness of the future world that he sets himself to destroy all the corrupt and cruel functionaries he can, and break the offices they fester in, till he's destroyed himself. [...] He's not a destroyer, he is destruction, leaving those good people who remain to build a better world on the ruins. (p. 259)

Samarin, so prompt to tolerate present suffering for future collective benefit, has little trouble accepting the idea of transforming his companions into meat. The destruction of the individual, here absolute as it involves his murder, butchery and ingestion, is again readily, and ironically, embraced as a necessary stage in the development of human society towards a more evolved state.

The presence of forces which can justify such abjection in the name of progress and necessity leave the human body constantly at prey to disintegration and abasement in the novel. When Samarin returns to civilisation he attempts to dispose of the final proof of his cannibalism: a gnawed hand which is all that remains of his victim. But he finishes by compounding the initial crime, since he dismembers another body, removing a second hand and discarding this too, in attempt to confuse anyone who might come across the initial remains (p. 16-19). Later, both hands will turn up again, the description of the first confirming the degradation endured as it has been rendered "old meat", transformed into a "putrid half-crab", the tendons resembling the "yellow core of chicken feet." (p. 246-247)

The castrates will also be likened to animals and beasts, with Samarin notably taunting Balashov, a former Cossack and keen horseman, that he "must feel like a centaur. Half man, half horse. Well, half man, whole horse." (p. 358) Other images of bestial abasement are used to stress that domination is first and foremost achieved through corporal subjugation. In an attempt to learn from his visions, the commanding officer of the Legion of Czech solders that occupy Yazyk, Captain Matula, has imprisoned a native Tungus shaman by chaining him to a kennel like a dog, thus reducing him to "a body slithering in the mud." (p. 39) The shaman's body already stands out as a symbol of organic disruption and compromised flesh: he bears three eyes, true to his role as a seer, although the third eye is merely a deformed tattoo over a bone lump which : protrudes from his forehead. This has then been scarred over with the word "LIAR" cut into the skin by an assailant (p. 48), an act of inscription that will later be replicated on the body of a murdered soldier who is found with a cryptic "M" scarring his forehead (p. 217). These signifiers cut into murdered flesh suggest the body has become a mere vehicle for the dominating, negating rhetoric of others, a medium devoid of its own signification or worth.

This question of human worth is neatly announced in the introductory description of Captain Mutz who is seen engraving his beloved Anna Petrovna (head and shoulders only, as the text specifies) to form the central illustration for a new billion-crown banknote to be used by the Czech soldiers (p. 36-37). As Mutz gouges out a face from cherry wood, the text prefigures the reification of the individual through a reversal of the carved faces that appear later. While Mutz acts out of love, it can be noted that Anna's likeness is to be used for an unofficial, devalued, inflation-weakened unit of monetary exchange, the fetishising of her beauty contrasting with the slogan "Liberty" 
which adorns the image. The theme of reification, here that of woman as the object of desire, is made more explicit through the character of Nekovar for whom the enigma of female arousal is forever discussed in terms of a mysterious, mechanical process ( $p$. 370-371). His failure to find this mechanism and repair it, leads him to conclude: "A man who doesn't please the ladies is a machine that knows it's broken, but it can't fix itself, because it can't see itself from the outside." (p. 312). What is absent from the automaton is of course the human vitality and emotion that remain the novel's central concern.

Nekovar's obsession with "examining ladies" (p. 313, my italics) or his description of a defective, near-human machine that cannot see itself can be set alongside Mutz's talents as an engraver in that they all highlight the power of the gaze to dissect the human body, understood as a possible corollary to the themes of bodily dismemberment and debasement ${ }^{11}$. The notion of a dehumanising gaze would go some way to explaining the profusion of references to sight and vision that can be found in what one reviewer has called "a novel of interrupted sightlines" highlighting the "perceived conflict between ideological vision and visible fact" ${ }^{12}$. Contrasting with Anna's early photography of peasants and workers, which provides a counter-example of an artistic vision with a strong humanist bent, her artist father's flawed portraits ultimately debase man: peasant children who have starved during a famine figure as a group of tiny mice (p. 76); his dying daughter merely represents a deluded occasion to exercise his vain talent for portraiture (p. 81). As for the two native Tungus, one blessed with second sight, the other a red-eyed albino, their key role is as witnesses to the acts of cannibalism and dismemberment. In addition to the seer who is witness to the spiritual disruption engendered by the act of cannibalism, the albino is the mysterious watcher in the woods who returns the severed hands that have been subsequently hidden and who keeps "the crows from the eyes" of the corpse in an effort to mitigate its physical destruction (p. 248).

The human body, whose degradation signals the problematisation of the passage from abstract idealism to the concrete application of those ideals, also appears in the novel as the catalyst for redemption and hope. This essentially operates through the character of Anna, Balashov's estranged wife and the lover of Mutz and Samarin, who is seen by the castrates as the antithesis of everything they believe in: worldly, selfish, mistrustful of dogma. Anna's sexual behaviour is openly described throughout the novel, prompting some commentators to see her as libidinous, as having an exaggerated corporeality as it were ${ }^{13}$. She is condemned as a fornicator by the sect, but her sexuality is just one facet of what grounds her in the imperfect, material world of human contact, desires and family relations so far removed from the "perfection and paradise" (p. 176) sought by the castrates. In the words of James Meek:

It wasn't so much her sexuality that I was putting in as a counterpoint, it was more her overall personality. The fact that she had this balance - or not a balance - a sort of swinging from one side to the other, in the sense that she knew that there were things she should do, and she knew that there were things she wanted to do. And she knew they weren't always the same thing. It's really all about individuals and closeness and intimacy and the individual versus the abstract and the conceptual.

The importance of Anna in the novel is that such grounding in the world of carnality, maternity, intimacy and contact is what ultimately causes the grand Utopian ideals of characters like Balashov and Samarin to fail. When Samarin compromises his escape from the Czechs, and thus his self-defined role as an agent of history, by returning the 
limp body of Anna's son Alyosha to her, Samarin laments that his revolutionary ideals are menaced by his own carnal desires. This is the replication of an earlier incident whose elucidation ironically invalidates the novel's title. Samarin's cannibalism, we learn, has not been the act of the escaping revolutionary requiring sustenance as he flees his captors, but of an ill-advised trek across Siberia in the vain hope of saving a female revolutionary whom he had loved as a student (p. 362). Samarin, wishing perhaps to preclude the existence of any more humane motives within him, interprets such weakness not as love, but as the product of lust. When he consequently asks Balashov to castrate him to avoid falling prey to further temptation, the parallel between cannibalism and castration is complete, even if his request is not upheld.

As for Balashov, his connection with Anna and their son Alyosha, both of whose presence in Yazyk testifies to his former state of undiminished masculinity, is what causes him to ultimately compromise his ideals of spiritual purity. His final act is to reject the pacifist teachings of his Skoptzy community in order to save Anna and the others by assassinating the insane Captain Matula. The graphic beheading of Matula results in Balashov's death and also, for the Skoptzy, in his eternal damnation since he has committed a mortal sin. His shunned corpse finishes as the unwelcome physical manifestation of a lost grace that, despite saving the town, still threatens to "pollute" his former spiritual brothers and sisters (p. 381). The novel finishes on a note of optimism, however: Balashov's heroism redeems him; Anna makes peace with her late husband and finds new love; the Czechs can finally return home. True to the novel's insistence on the theme of bodily mutilation, this is paradoxically made possible only by Matula's decapitation and Balashov's final instance of blood (self-)sacrifice.

\section{Ideological cannibalism}

More's original play on words underlines how the Eu-topian always cedes to the Utopian ${ }^{14}$. In The People's Act of Love, it is the human body which becomes the key locus of this conflict, as the will of the spirit encounters the resistance of the flesh. As such it is through the body that the novel announces the ultimate failure of Utopian ideals. In interview, James Meek discusses how attempts to realise Utopian ideals have fared in history, returning to the failings of a mechanistic view of human existence:

There are some interesting examples from America, from Utopian communities which were set up in the wilderness - little towns, a blank sheet of paper where some very strong personality was able to write their holy writ, or their thesis. And indeed you could argue that was what the Mormon church was all about. But there was one particular example, "Bible Communism", I think that was the actual name for it: one town with a few hundred inhabitants, and a single man by the force of his personality, while he was alive, was able to make this work. At least for a time. And I don't know how high you're setting the bar of what counts as working and how many people actually suffered a great deal personally in this working, but there was a kind of functioning and a success to it. But as soon as the man died, it failed.

So it may be that on a very small scale, with a single strong personality, an individual who is united with the very ideal that he or she is trying to put forward, that they can bring together a small community for a short time while they are alive in a kind of Utopian existence. Or at least following a new sort of rules, obediently. But that's really as far as you can imagine it going.

It's the problem of trying to insert in human beings some alternative clockwork with the idea that you can then just wind them up and set them going and they will 
be autonomously idealised. It doesn't work. It's never worked. And yet people keep on believing that it will.

Because of the irresolvable nature of the dialectic between the spirit and the flesh, the ideal and the individual, the Utopian solutions proposed in Meek's novel all ultimately diminish man. Saramin, who does not share the castrates' religious convictions, nevertheless praises their self-mutilation as uplifting hope that man can indeed surpass himself (p. 293) and merely asks "Are there to be no ideals?" (p. 260) when the cannibal's actions are criticised as vain. James Meek describes Samarin's nihilistic vision in this way:

It's the old conundrum of "Is darkness the absence of light, or is light the absence of darkness?" and his idea is not that humanity needs something extra, something given to it, in order to be happy and at peace. His idea is that it needs something to be taken away. Which in a way is the same as Balashov's belief - and I don't mean that in the literal, bodily sense - but in the very traditional, Christian, religious sense of the tension between your corporeal form and your spiritual form. That the one is holding the other one back.

Due to its agrarian focus, some would contest that the idealism of the castrates is more Arcadian than Utopian ${ }^{15}$. Their stated vision is overtly reactionary, however, a regressive return to an Edenic state of uncompromised plenitude and purity (p.57). Beyond the immediate impression of a lost wholeness, this state may symbolise, at an ideological level, what their genital mutilation and sectioned bodies evoke at a psychoanalytical level: the ambivalent attraction and repulsion elicited by fantasies of a return to the maternal womb ${ }^{16}$.

The novel draws many, often ironic, parallels between the political and the spiritual variants of the Utopianism attempted, such as the encounter between the castrates' pacifist community, based on brotherhood and shared property, and the Bolsheviks who come to liberate them with a similar message, then make off with their provisions (p. 57). The meetings between Samarin and Balashov suggest that beyond their obvious human and ideological differences, their Utopian doctrines revolve around a shared core of sacrifice and renouncement, whether imposed on oneself or on others. Samarin's Utopia will be one of cold rationality, where the self-assured intellect is able to master itself the same way as it reasons away its qualms about human suffering. This is echoed by the commander of the Bolsheviks who have returned and are now waiting to massacre the Czechs, Communist sympathisers and all, as enemies of the people: "Communist man will be the master of his passions." (p. 319) Similarly, Samarin's tales of the suffering he has endured in an Arctic camp for dissidents of the Tsarist regime are shown to be no more than the product of his prodigious imagination, but Mutz, in a thinly veiled allusion to the Soviet Gulag for the modern reader, understands the significance of this as a portent of what is to come: "a premonition of the righteous retribution of the Tsar's enemies." (p. 354) Samarin's stance is thus again likened to that of the Bolsheviks, and it is they who consider the act of cannibalism as being conceivable within Communism, so long as the proper administrative procedures are followed:

Bondarenko thought for a while. 'There would have to be a very good reason,' he said.

'Sweet reason!' said the doctor.

'And, of course, a plenary meeting of the relevant Soviet, with a vote.'

'Reason, justice and cannibalism,' said the doctor. 'Utopia!' (p. 320) 
We can note that it is the Bolsheviks' doctor, for whom human suffering is a more immediate preoccupation perhaps, who is the one to react ironically to such a view. Bondarenko's calm rationalisation of abjection, the subordination of the individual to an ideology, shows the novel's key concern with totalitarianism, the inescapable subtext of any modern portrayal of Utopia, too conscious of the twentieth-century examples of human annihilation in the name of collective improvement ${ }^{17}$. Meek's choice of cannibalism as a central motif literalises the analysis of Nikola Kovac, whose definition of the political novel is concerned with the mechanisms of totalitarian regimes and who describes both the modern era's death camps and the medieval auto$d a-f e ́$ as the bloody rites of "ideological cannibalism"18. A novel such as The People's Act of Love also inevitably bears within itself the trace of the great twentieth-century literary dystopias. Meek has himself compared the novel to 1984 for its exploration of the destruction inherent in the love of an ideal ${ }^{19}$, while his novel also relates to the specific failings of the Soviet model of which the author had firsthand experience:

Having lived there, and having lived there, at least initially, not as somebody who flies in on a big western salary and lives in a bubble, but as somebody who is living a comfortable life, certainly, with dollars, but close to the lives that the Russians and the Ukrainians led, and travelling a lot, certainly travelling a great deal more in those turbulent times than almost any Russian or Ukrainian would have the opportunity to do, I was certainly struck by the extraordinary manifestations of emerging capitalism. But I was more persuaded of the failures of Communism in practice than I was by the idea that the opening up or the destruction of that system was a disaster.

However, Meek is also wary of the historiographic impulses that can be imputed to a novel such as his, and indeed views the historical novel, as a genre, with circumspection. Instead, he appeals for a more universalist reading of the novel:

I wish I could have been writing about something more contemporary. I really wish I hadn't had to make a historical novel. I didn't want to write a historical novel. I don't like the idea still. That was the only way of doing it. It wouldn't have worked. If it hadn't been a historical novel then it would have been even worse, namely a fantasy novel. I don't want to rule myself out of writing anything in the future, but I just think my problem with historical novels is that there is so much baggage attached to them. And there are so many of them about. And there are so many bad ones. And there's a particular genre, which I abhor, of writers who want to have it both ways, where they want to be admired for the veracity of their research, but they're not prepared to put the work in to actually make a brilliant work of nonfiction. [...]

I would just like to get beyond all that and get down to the human stories, to the aspects of human nature in extremists that the stories are about. And the fact that it's set in Russia in 1919 - I would much rather that it was incidental and that people saw it as incidental. I don't want sound as though I'm comparing myself to shakespeare, because I'm not, but if he'd been on Radio 4 on Start the Week in 1599, would he have been introduced as a man who'd just written a play about Denmark when they were talking about Hamlet? Or about Scotland when they were talking about Macbeth?

\section{Utopia in troubled times}

Despite the significant differences with James Meek's earlier fiction, The People's Act of Love, through its central preoccupation with Utopian systems and the degradation of 
the individual, offers a new perspective on his other works. The short story that Meek published in the first Clocktower Press booklet and which he also then chose to introduce his first collection, Last Orders, is entitled "Safe". The narrative focuses on Fergus, a disturbed, paranoid character who feels he is being persecuted by the vaguely-defined agents of a dictatorial state. Fergus intends to make his way to a travel agents in a bid to flee the country, expressing in the opening lines the possibility that this flight may lead him "to the ends of the earth" (in Last Orders, p. 1). The ultimate impossibility of actually finding a safe haven is thus already sketched out in this incipit, confirmed in a later dialogue in the travel agents:

To be totally honest with you, said Fergus, I'm a bit disappointed with the choice of countries.

That's a map of the world. That's all the countries there are.

I know, but I mean it just seems they've left something out. (p. 7)

Fergus's anticipation of arriving in a perfect land where he will be at peace, and his dissatisfaction with the possibilities offered by the real world, are clearly presented as the absurd products of a deluded mental state. By stating the impossibility of such escape, Meek's short story works as a paranoid literalisation of Baudelaire's "Any where out of the world", the poetic expression of Utopia as the vain physical flight from destinations which can but fail to break with the reality of existence and experience ${ }^{20}$.

This underlining of U-topia's inherent placelessness informs the central problematic of the postmodernist Drivetime, which takes the form of a fruitless quest for an elusive object across a Europe of nameless countries, shifting localities and cyclical timeframes. Drivetime's constant invalidation of a sense of place is the antithesis of The People's Act of Love ${ }^{21}$. However, the assimilation of grand quests with delusion ${ }^{22}$ again ultimately suggests the supremacy of tangible human experience over fraught idealism. The metaphor for the failure of this idealism is, from the outset, signalled by images of absent locality: the road-trip narrative's first halt is significantly at a "non-existent village" (p. 54).

Drivetime also calls us to reflect upon the individual's problematic identity in a world of signifiers and discourse, notably through onomastic disturbances such as the profusion of doubled-up, identical, alliterative or near-palindromic character names. The disruption is also highlighted in the description of the Latin "NEMO" scarred in part across one character's chest in a revenge attack (p. 109). Carved out by an aggressor called D-D, the letters "NEM" are not only the symbol of negated identity (reducing the individual to an incomplete nobody, as it were), they are also short for D-D's call for retaliation in the face of a slight, "Nemo me impune lacessit", which is of course the Royal Scottish motto, present on Scottish heraldry as well as on Scottish-edition pound coins of the 1980s and 1990s. All of these elements - the alliterative character names, the signifiers scarred into human flesh, the hinting at the individual's reification and depreciation (as a unit of currency, a prime instance of metonymic substitution) - are later reworked in The People's Act of Love ${ }^{23}$. In Drivetime the evocation of corrupt authorities in the Northern Caucasus burning down homes or beating and executing prisoners (p. 250-253) also illustrates Meek's concern with brutal regimes and their tyrants and functionaries. The short story "The Brown Pint of Courage" (in Children of Albion Rovers, p. 67-93) describes the actions of a deranged chief traffic warden who prefigures Captain Matula's dreams of absolute power and subjugation through his adoption of the title "Commendatore", which conjures up images of Italian fascism. 
Although the idiosyncrasy of the character lessens his import, the Commendatore's actions announce a now familiar contempt of the human as he destroys likenesses of his subordinates in a simulacra of dismemberment and cannibalism:

He picked up the two male figures in turn and cut off their heads and their legs, then put them in his mouth and chewed them. Still chewing, he laid the female figure in an ashtray, lit a match and set fire to it. (p. 82)

Similar themes reappear in stories such as "Recruitment in Troubled Times" (in Last Orders, p. 97-116), which deals with the recruitment of a state torturer for a Republican Catholic Scottish Commonwealth under attack from English suicide bombers. In this short story, published in 1992, the fictional state's measured legitimisation of torture when faced with terrorism and fanaticism pre-dates Meek's journalistic work on the abuses perpetrated in the name of the post-9/11 "Global War on Terror". In the story, official rhetoric affirms how the application of "physical force" on a "repeatedly recalcitrant subject" has as its end goal "the welfare of the majority of the body politic" (my italics, p. 99). This echoes the commentary of Alan Bissett, who, writing of a modern Gothic tradition in Scotland, describes the Gothic as "the shocking return to the power of blood", and states: "The Gothic has always provided a political subtext beneath the slavering exterior, as much concerned with the body of the state as the state of the body ${ }^{24}$ ". In Meek's short story the connection between the victim and statesponsored perpetrator of torture is rendered by means of the same corporeal metaphor, with the physical degradation of the former reflecting the moral degradation of the latter. The connection between body and body politic is equally present in The People's Act of Love through Anna's critique of brutal regimes and ideologies as corrupted from within by the bloody acts which found or support them (p. 294).

Though The People's Act of Love shies from the self-reflexivity of some earlier works, it maintains a keen sense of the power of discourse to fashion behaviours, provide moral justification for abominable acts and inspire devotion. These themes are explored more explicitly elsewhere. For example, in Meek's short story "Bonny Boat Speed" (in The Museum of Doubt, p. 28-46), the moulding of the real by dint of plausible, but totally spurious, statements is alluded to through the figure of a freelance journalist who specialises in invented apocrypha. Asked whether the awareness of worlds being not merely transposed, but constructed and contained by language, was in any way heightened by his own role as a journalist, Meek demurs:

I think looking at it in terms of journalism is too narrow. Everyone uses words. It's very easy to make something more special and more peculiar about the business of journalism than it actually is. There are lots of people who live their whole lives with words and earn a living by it and do great good, or more likely great damage, with words, but are neither writers nor journalists: teachers, politicians, businessmen, salesmen.

Indeed, the figure of a demoniacal salesman dominates the title story of the collection The Museum of Doubt (p. 1-27), his sales pitch and its undisguised Faustian pact becoming a critique of the values underlying our consumerist society. As in the novel McFarlane Boils the Sea, where descriptions of modern capitalism reveal a deeply dehumanising impetus - the enterprising landlord who divides up a guest-house into stifling, miniscule cubicles for benefit recipients (p.128); the dockside renovations where new luxury flats with sandblasted walls have removed all traces of a soiled industrial past (p. 33) -, Meek's fiction continues to judge the discourse of progress by 
comparing abstraction with application, by adamantly stating the worth of individual lives over that of ideals.

The People's Act of Love has been praised by, among others, an extremely broad spectrum of Scottish writers, ranging notably from Irvine Welsh to Allan Massie ${ }^{25}$. While this suggests that with this novel Meek has managed to secure a federating position within Scottish letters, it is also true that this same work singularly, and positively, problematises the notion of Scottish fiction and its boundaries. Carla Sassi has discussed how the line of demarcation between the Scottish and British canon typically set perceived local/national particularity against the perceived universalism of a more anglicised tradition ${ }^{26}$. Such acts of literary cartography, and the artificial sense of exclusive traditions that they engender, are certainly at odds with the complexity evidenced by the Russian focus of a novel published in Edinburgh by an English-born author who grew up and began writing in Scotland but who now lives in London. James Meek is himself, at best, ambivalent about such labelling:

I'm happy up to a point for people to describe me or think of me as a Scottish writer. I'm certainly happy to be thought of as a writer from Scotland. And really, whoever is going around sticking St Andrew's crosses on books, if they want to stick one on mine, they're welcome. I don't know. How would I feel if I walked into Waterstone's in Princes Street and saw The People's Act of Love sitting on the Scottish books shelves? I might find that a little strange. I think I find the idea of putting Scottish novels in Scottish bookshops, on a special shelf of their own, slightly odd. Sometimes they are and sometimes they aren't. The intention is not malicious or patronising, but it still makes me feel a little uneasy. [...]

I think perhaps the ideal is that you just go on, steadily producing work, people read you and some people who like more than one of your books do start to see a sort of meta-novel emerging and you are both of a place, but a writer. I guess you're trying to find that mean where you are a writer from Scotland, but also a writer. In the same way that Seamus Heaney is an Irish poet, but he's a poet as well. He's found that balance. But of course, it's not him really. He just writes the poetry. It's just this buzz around the work and what you really have to do as a writer is not give a fuck about that. That's someone else's issue.

It is certain that James Meek's anthropophagic revolutionaries and castrating fundamentalists, his insistence on blood sacrifice and torture, form a literature which harbours scant illusion about what Alan Bissett refers to as the "safety of the flesh ${ }^{27}$ ". But it must be remembered that Meek's vastly imaginative and varied oeuvre, for all the blood shed, or indeed because of it, remains deeply humanist. In The People's Act of Love, Mutz, facing execution at the hands of the Bolsheviks, imagines staring at his own corpse in the snow, and expresses amazement that "this wonderful machine could be so simply stopped." (p. 323) It is against this fragility of the body that Meek's fiction underlines how terrible the power of the Idea can become, particularly if human life, in all its frailty, is subordinated to an Idea now found to possess "men, and armoured trains, and land." (p. 277) In this respect, his writing corresponds perfectly to what Raymond Trousson describes as a twentieth-century view of Utopia, wherein the sacrifices required to engineer the perfect community deliver the proof by the absurd that man should, at all times, be considered an end rather than a means ${ }^{28}$. 


\section{BIBLIOGRAPHY}

\section{Fictional works cited}

MEEK James, McFarlane Boils The Sea, Edinburgh, Polygon, 1989.

-, Last Orders, Edinburgh, Polygon, 1992.

-, Drivetime, Edinburgh, Polygon, 1995.

-, "The Brown Pint of Courage" in Kevin Williamson (ed.), Children of Albion Rovers, Edinburgh, Rebel Inc., 1996, p. 67-93.

-, The Museum of Doubt, Edinburgh, Rebel Inc., 2000.

-, The People's Act of Love, Edinburgh, Polygon, 2005.

\section{NOTES}

1. See, for example, James Meek, "Speaking a different language - but we've got the Phrasealator", The Guardian, 31-3-2003.

2. James Meek, "People the law forgot", The Guardian, 3-12-2003.

3. The novel, translated into twenty languages, has just been published in France by Métailié under the title "Un acte d'amour".

4. Duncan McLean, "Time Bombs: a short history of the Clocktower Press" in Duncan McLean (ed.), ahead of its time: a Clocktower Press anthology, London, Jonathan Cape, 1997, p. ix-xii.

5. David Lodge, The Modes of Modern Writing, London, Edward Arnold, 1977, p. 231, p. 239-240.

6. Tzvetan Todorov, Introduction à la littérature fantastique, Paris, Éditions du Seuil, 1970, p. 29.

7. Marie-Odile Pittin-Hédon, "Postmodern Fantasy: the Supernatural in Gray's Comedy of the White Dog and Welsh's Granton Star Cause", Études écossaises, n 7, 2001, p. 61-74.

8. All comments by James Meek are taken from an interview with the author conducted in the British Library on January 26, 2007.

9. Claude-Gilbert Dubois, Problèmes de l'utopie, Archives des Lettres modernes, n 85, 1968, p. 21.

10. Micheline Hugues, L'Utopie, Paris, Nathan, 1999, p. 74.

11. Mélanie Pellerin, "Le corps morcelé dans quelques nouvelles de J. S. Le Fanu" in Françoise Dupeyron-Lafay (ed.), Les représentations du corps dans les œuvres fantastiques et de science-fiction : figures et fantasmes, Paris, Michel Houdiard, 2005, p. 95.

12. "A boil of armies in wildest Russia", Telegraph.co.uk [online newspaper], 4-7-2005, <http:// www.telegraph.co.uk/arts/main.jhtml?xml=/arts/2005/07/03/bomee03.xml\&sSheet=/arts/ 2005/07/03/bomain.html>, consulted March 2007.

13. See, for example, David Ramos Fernandes, "Interview with James Meek", The Barcelona Review [online journal], no.51, January-February 2006, <http://www.barcelonareview.com/51/ e_int.htm>, consulted March 2007.

14. Raymond Trousson, Voyages aux pays de nulle part : histoire littéraire de la pensée utopique, Brussels, Éditions de l'université de Bruxelles, 1999, p. 9-10.

15. Claude-Gilbert Dubois, Problèmes de l'utopie, p. 20, p. 25.

16. Mélanie Pellerin, “Le corps morcelé dans quelques nouvelles de J. S. Le Fanu”, p. 104.

17. Micheline Hugue, L'Utopie, p. 114.

18. Nikola Kovac, Le Roman politique: fictions du totalitarisme, Paris, Éditions Michalon, 2002, p. 227. 
19. Nigel Beale, "James Meek Russian: Audio Interview with Nigel Beale" < http:// nigelbeale.com/?p=251 [online review], 2006>, consulted January 2007.

20. See Claude-Gilbert Dubois, Problèmes de l'utopie, p. 41.

21. The Ondaatje prize, attributed to the novel in 2006, is awarded precisely for a work, fictional or not, "evoking the spirit of a place." See <www.rslit.org/ondaatje_text.htm> [Royal Society of Literature website], consulted March 2007.

22. In the closing chapters, the search for the decorated egg notably leads the central character to a lunatic asylum where he is himself incarcerated. He then escapes by driving, disabused, through seemingly endless grounds and reaches home without ever having crossed again the barrier between the real world and the asylum.

23. See the discussion of alliterative signifiers elicited by the carving of the letter " $M$ " into the dead soldier's forehead. James Meeek, The People's Act of Love, p. 217.

24. Alan Bissett, “'The Dead Can Sing': An Introduction” in Alan Bissett (ed.), Damage Land: New Scottish Gothic Fiction, Edinburgh, Polygon, 2001, p. 6-7.

25. See notably Irvine Welsh's hagiographic review, "A hymn to humanity", The Guardian, 9-7-2005.

26. Carla Sassi, "Re-establishing Complexities: Researching and Teaching Scottish Literature inside/outside Scotland", International Journal of Scottish Literature [online journal], no. 1, Autumn 2006, www.ijsl.stir.ac.uk, consulted January 2007.

27. Alan Bissett, "The Dead Can Sing", p. 5.

28. Raymond Trousson, Voyages aux pays de nulle part, p. 272.

\section{AUTHOR}

\section{DAVID LEISHMAN}

Université Stendhal-Grenoble 3 